Review

\title{
Long Non-Coding RNAs and Complex Human Diseases
}

\author{
Jing $\mathrm{Li}^{1, \dagger}$, Zhenyu Xuan ${ }^{2, *}$ and Changning Liu ${ }^{1, *}$
}

1 Bioinformatics Research Group, Key Laboratory of Intelligent Information Processing,

Advanced Computer Research Center, Institute of Computing Technology,

Chinese Academy of Sciences, Beijing 100190, China; E-Mail: lij.thu@gmail.com

2 Department of Molecular and Cell Biology, Center for Systems Biology,

University of Texas at Dallas, 800 W Campbell Road, Richardson, TX 75080, USA

$\dagger$ Present address: School of Medicine, Tsinghua University, Beijing 100084, China.

* Authors to whom correspondence should be addressed: E-Mails: zhenyu.xuan@utdallas.edu (Z.X.);

lcn@ict.ac.cn (C.L.); Tel.: +1-972-883-2518 (Z.X.); +86-10-6260-1010 (C.L.);

Fax: +1-972-883-5710 (Z.X.); +86-10-6260-1356 (C.L.).

Received: 20 June 2013; in revised form: 28 August 2013 / Accepted: 3 September 2013 /

Published: 12 September 2013

\begin{abstract}
Long non-coding RNAs (lncRNAs) are a heterogeneous class of RNAs that are generally defined as non-protein-coding transcripts longer than 200 nucleotides. Recently, an increasing number of studies have shown that lncRNAs can be involved in various critical biological processes, such as chromatin remodeling, gene transcription, and protein transport and trafficking. Moreover, lncRNAs are dysregulated in a number of complex human diseases, including coronary artery diseases, autoimmune diseases, neurological disorders, and various cancers, which indicates their important roles in these diseases. Here, we reviewed the current understanding of lncRNAs, including their definition and subclassification, regulatory functions, and potential roles in different types of complex human diseases.
\end{abstract}

Keywords: non-coding RNA; long non-coding RNA; complex human disease

\section{Introduction}

While about 20,000 protein-coding genes, representing less than $2 \%$ of the human genome, have been reported [1,2], a large part of the genome can be transcribed into non-coding RNAs (ncRNAs), which 
have little or no protein-coding capability [3,4]. Besides many widely studied classes of short ncRNAs, such as microRNAs (miRNA) and Piwi-interacting RNAs (piRNA) [5,6], one class of heterogeneous ncRNAs with lengths longer than 200 nucleotides, recently designated as long non-coding RNAs (lncRNAs), is increasingly attracting the attention of ncRNA researchers [7,8].

Over the past decade, furthered by the rapid progress in high-throughput sequencing technology, thousands of IncRNAs have been identified in mammalian transcriptomes [9,10]. A number of studies have revealed that lncRNAs can participate in various critical biological processes, such as chromatin remodeling, gene transcription, and protein transport and trafficking [11,12], implicating their impact on a wide range of complex human diseases $[13,14]$. However, despite some well-characterized lncRNAs, such as Xist and HOTAIR [15,16], little is known about the general features of most lncRNAs, such as gene structure, transcriptional regulation, and functional domains, and even less is known about their possible molecular mechanisms in different human diseases. Understanding the function of lncRNAs remains a significant challenge. Here, we review the current literature reporting on lncRNAs, including their definition, subclassification, regulatory functions, and roles in different types of complex human diseases.

\section{Long Non-Coding RNAs: A Heterogeneous Class of RNAs}

Long non-coding RNAs are most commonly defined as an RNA transcript more than 200 nucleotides (nt) long that cannot be translated into a protein [17]. However, this length threshold is not strict; it may vary 100 to $200 \mathrm{nt}$, or even longer. In different biochemical fractionation protocols, this threshold is primarily used to exclude most of the categories of small RNAs, such as small nucleolar RNA (snoRNA), microRNA (miRNA), Piwi-interacting RNA (piRNA), transfer RNA (tRNA), and small nuclear RNA (snRNA). Therefore, according to these simple criteria of transcript size and protein-coding capability, the designated lncRNAs contain a group of structurally and functionally heterogeneous RNAs, having a length that varies from approximately $200 \mathrm{nt}$ to over $100 \mathrm{~kb}$. They can undergo either splicing or not, with cellular locations in either nucleus or cytoplasm. They can be transcribed by RNA polymerase II or III, and they can play different functional and structural roles in different biological processes [18]. Based on these features, lncRNAs can be further categorized into different subgroups, as listed in Table 1. In past years, along with in-depth studies of lncRNAs, several IncRNA databases have been constructed (Table 2). These databases can facilitate further functional research on lncRNAs.

Table 1. Types of long non-coding RNAs.

\begin{tabular}{ccc}
\hline Long non-coding RNA & Symbol & References \\
\hline Long intergenic non-coding RNA & LincRNA & {$[19,20]$} \\
Long intronic non-coding RNA & & {$[14,21]$} \\
Natural antisense transcript & NAT & {$[22-24]$} \\
Promoter-associated long RNA & PALR & {$[25]$} \\
Promoter upstream transcript & PROMPT & {$[26]$} \\
Transcribed pseudogene & & {$[27-29]$} \\
Transcribed ultraconserved region & & {$[30,31]$} \\
Enhancer-like non-coding RNA & T-UCR & {$[32]$} \\
& eRNA & {$[33]$} \\
\hline
\end{tabular}


Table 2. Public lncRNA databases.

\begin{tabular}{ccc}
\hline Name & Website & Reference \\
\hline ChIPBase & http://deepbase.sysu.edu.cn/chipbase/ & {$[34]$} \\
fRNAdb & http://www.ncrna.org/frnadb/ & {$[35]$} \\
LNCipedia & http://www.lncipedia.org/ & {$[36]$} \\
lncRNAdb & http://www.lncrnadb.org/ & {$[37]$} \\
NONCODE & http://www.noncode.org/ & {$[9]$} \\
NRED & http://nred.matticklab.com/cgi-bin/ncrnadb.pl & {$[38]$} \\
\hline
\end{tabular}

Genome-wide transcriptional maps have shown that lncRNAs are pervasively transcribed throughout mammalian genomes $[39,40]$. Clusters of overlapping sense and antisense transcripts can be found inside of known genes, as well as in intergenic regions. Natural antisense transcripts (NATs), which have been largely discovered in human, mouse, and many other species, are endogenous RNA molecules that exhibit partial or complete complementarities to other transcripts [22-24]. NATs may regulate the expression level of their sense counterparts. Several plausible regulation models, like blocking translation by sense-antisense pairing or antisense RNA-directed chromatin remodeling, have been proposed $[13,41]$. However, little mechanistic information has supported these suppositions, and more intensive studies are needed. Unlike NATs, long intergenic non-coding RNAs (lincRNAs) are large multiexonic RNAs, which are transcribed from intergenic regions, and may act in trans within large ribonucleoprotein complexes [10,19,42]. For example, Huarte et al. have reported that lincRNA-p21, which can physically interact with hnRNP-K, serves as a repressor in p53-dependent transcriptional responses by modulating hnRNP-K localization to chromatin [43]. A recent comprehensive screen has identified dozens of lincRNAs, which bind to multiple chromatin regulatory proteins, to affect related gene expression procedures and function critically in the pathway controlling pluripotent embryonic stem cell (ES) state [20]. Long non-coding RNAs have also been transcribed from widespread repetitive elements. For instance, human Alu and mouse B2 RNAs are originally derived from short interspersed repeat elements (SINEs). They are transcribed by RNA polymerase III in response to environmental stresses, such as heat shock, and act as transcriptional repressors by directly targeting RNA polymerase II [27-29]. Another interesting example is lncRNA PTENP1, a biologically active pseudogene of the tumor suppressor gene Phosphatase and Tensin Homolog (PTEN). PTENP1 performs a tumor suppressive function by acting as an "endogenous miRNA sponge", which can positively regulate PTEN protein level via competing for PTEN-targeting miRNA binding [30,31].

Unlike protein-coding genes, which are usually conserved across species, most lncRNAs are poorly conserved and have been taken for transcriptional noise [44]. However, lack of conservation does not mean lack of function $[45,46]$. For example, two lncRNAs, Antisense Igf2r RNA (Air) and X Specific Transcript (Xist), are poorly conserved, but are well functional $[47,48]$. Their subjection to a series of recent and rapid adaptive selections may provide one explanation for the poor conservation of lncRNAs. For example, Highly Accelerated Region 1F (HAR1F), an lncRNA which is exclusively expressed in Cajal-Retzius neurons in the human neocortex, has undergone rapid evolutionary change in the human lineage since our last common ancestor of chimpanzee [49]. Moreover, for lncRNAs, which exert functions by secondary structures or short sequence motifs, we may only find small conserved regions interspersed in long poorly conserved transcripts [50]. Besides those poorly conserved lncRNAs, 
non-coding transcripts can also be transcribed from ultraconserved genomic regions (UCRs). UCRs were first discovered in the sequence comparison of mouse, rat, and human genomes [51]. They are genomic elements longer than 200 bp with $100 \%$ identity between orthologous regions in these three genomes $[52,53]$. Genomic variations in UCRs, such as single nucleotide polymorphisms (SNPs), have been reported to be associated with increased cancer risk [54]. Genome-wide expression profiling has revealed that a large fraction of UCRs are transcribed (transcribed-UCRs, T-UCRs) with significant alteration at both DNA and RNA levels in adult chronic lymphocytic leukemias, as well as colorectal and hepatocellular carcinomas [32,55]. Recent study in neuroblastoma has discovered the relevance between expression levels of specific T-UCRs and important clinical-genetic parameters, suggesting that T-UCRs may be used as signatures associated with cancer diagnosis, prognosis, and treatment [55].

As a heterogeneous class of RNAs, IncRNAs have been implicated in the regulation of a number of complicated biological processes. A study in human cell lines suggests that about $30 \%$ of lncRNAs are specifically expressed in the nucleus [25]. Many of them are involved in chromatin remodeling complexes and mediate genomic silencing [10]. One of the most well-known examples is the participation of IncRNAs in X-chromosome inactivation (XCI), a process by which one of the two copies of the $X$ chromosome present in female mammals is inactivated [15]. During XCI, Inactive $X$ Specific Transcript (Xist), a 17-kb lncRNA transcribed from the XCI center, will accumulate on the inactive $\mathrm{X}$ chromosome and recruit Polycomb complexes for subsequent epigenetic modifications. Its antisense counterpart, Tsix, which is another lncRNA specifically expressed from the other $\mathrm{X}$ chromosome, can also interact with Polycomb complexes and maintain the activity of $\mathrm{X}$ chromosome [48]. Apart from in trans regulation, some lncRNAs can directly regulate gene expression in cis. By using knockdown approaches and reporter assays, Orom et al. have discovered an enhancer-like effect for a set of lncRNAs in human cell lines [56]. Depletion of these lncRNAs leads to decreased expression of their neighboring protein-coding genes. More interestingly, a recent genome-wide study of transcriptional enhancers in mouse has shown that some lncRNAs, termed as enhancer-RNAs (eRNAs), are transcribed from functional enhancers [33]. Although the function of eRNAs remains largely unclear, their close correlation with active enhancers suggests an important role of eRNAs in transcriptional activation. Long non-coding RNAs are also actively involved in diverse cytoplasmic processes. One of the well-studied examples is noncoding repressor of NFAT (NRON), an IncRNA repressor of nuclear factor of activated T cells (NFAT). Using an arrayed library of short hairpin RNAs and cell-based assays, Willingham et al. have identified that NRON interacts with multiple proteins, including members of the importin-beta superfamily, and possibly functions as a specific regulator of NFAT nuclear trafficking [57]. Moreover, lncRNAs are probably involved in stress-related signaling pathways. Utilizing whole-genome tiling arrays, Silva et al. identified a new class of long stress responsive non-coding transcripts (LSINCTs), which have increased expression in response to DNA damage induced by the tobacco carcinogen 4-(methylnitrosamino)-1-(3-pyridyl)-1-butanone (NNK) [58]. Interestingly, LSINCTs also have increased expression in a number of cancer-derived cell lines, indicating its stress response under a carcinogenic environment. 


\section{Long Non-Coding RNAs and Complex Human Diseases}

Complex diseases are multifactorial or polygenic disorders of the body. They are likely caused by multiple genetic variants with low penetrance in combination with various environmental and lifestyle factors, and they do not simply obey the standard Mendelian patterns of inheritance [59,60]. Coronary artery diseases, autoimmune diseases, neurological disorders, various cancers, and many other diseases all belong within this classification. The recent discovery that lncRNAs can participate in a wide range of biological processes has attracted substantial scientific interest in their potential impact on these complex diseases. It has been reported that lncRNAs are dysregulated in a variety of complex human diseases and are closely associated with disease development and progression (Table 3). Here, we describe some of the well-characterized lncRNAs associated with different types of complex human diseases.

Table 3. Examples of lncRNAs dysregulated in complex human diseases.

\begin{tabular}{|c|c|c|}
\hline LncRNA & Disease & References \\
\hline $\mathrm{aHIF}$ & Multiple cancers & {$[61,62]$} \\
\hline AK023948 & Papillary thyroid carcinoma & {$[63]$} \\
\hline ANRIL & Coronary artery disease; Multiple cancers & [64-68] \\
\hline ASFMR1 & Fragile $\mathrm{X}$ syndrome; Fragile $\mathrm{X}$ tremor ataxia syndrome & {$[69]$} \\
\hline ATXN8OS & Spinocerebellar ataxia type 8 & {$[70]$} \\
\hline BACE1-AS & Alzheimer's disease & {$[71]$} \\
\hline $\mathrm{BC} 200$ & Alzheimer's disease; Multiple cancers & [72-74] \\
\hline $\mathrm{BIC}$ & B-cell lymphoma & {$[75]$} \\
\hline CUDR & Squamous carcinoma & {$[76]$} \\
\hline DD3 & Prostate cancer & {$[77,78]$} \\
\hline FMR4 & Fragile $\mathrm{X}$ syndrome; Fragile $\mathrm{X}$ tremor ataxia syndrome & {$[79]$} \\
\hline GAS5 & Breast cancer & {$[80]$} \\
\hline H19 & Multiple cancers & [81-85] \\
\hline HOTAIR & Multiple cancers & {$[16,86]$} \\
\hline HULC & Multiple cancers & {$[87,88]$} \\
\hline Kenq1ot 1 & Colon cancer & [89] \\
\hline Kras1p & Prostate cancer & {$[30]$} \\
\hline Linc-p21 & Lung cancer & [43] \\
\hline LOC285194 & Osteosarcoma & {$[90]$} \\
\hline MALAT-1 & Multiple cancers & [91-93] \\
\hline MEG3 & Multiple cancers & [94-97] \\
\hline MIAT & Myocardial infarction & [98] \\
\hline ncRAN & Neuroblastoma & {$[99,100]$} \\
\hline NDM29 & Neuroblastoma & [101] \\
\hline PCGEM1 & Prostate cancer & [102] \\
\hline PRINS & Psoriasis & [103] \\
\hline PRNCR1 & Prostate cancer & [104] \\
\hline PTENP1 & Prostate cancer & {$[30]$} \\
\hline RMRP & Leukemia and lymphoma & [105] \\
\hline SAS-ZFAT & Autoimmune thyroid disease & [106] \\
\hline
\end{tabular}


Table 3. Cont.

\begin{tabular}{ccc}
\hline LncRNA & Disease & References \\
\hline SPRY4-IT1 & Melanoma & {$[107]$} \\
SRA-1 & Breast cancer & {$[108,109]$} \\
TERC & Multiple cancers & {$[110]$} \\
Ube3a-as & Angelman syndrome & {$[111,112]$} \\
uc.73A & Colon cancer & {$[32]$} \\
UCA1 & Bladder cancer & {$[113-115]$} \\
Zfas1 & Breast cancer & {$[116]$} \\
\hline
\end{tabular}

\subsection{LncRNAs in Coronary Artery Diseases}

Facilitated by single nucleotide polymorphism (SNP) array, genome-wide association study (GWAS) is becoming one of the most powerful approaches to identify genetic variants susceptible to common diseases [117]. From these studies, a large amount of disease-associated SNPs are found to be mapped to non-coding genomic regions. While some of these SNPs could be associated with enhancers, it would not be surprising that many others are associated with lncRNAs. By using 52,608 haplotype-based SNP markers, the lncRNA called Myocardial Infarction Associated Transcript (MIAT) was first identified in a large-scale case-control association study of the samples from $3435 \mathrm{MI}$ patients and 3774 controls [98]. MIAT dwells at a susceptible locus for myocardial infarction (MI) on chromosome 22q12.1. This study discovered six SNPs showing significant association with MI in this locus. The MIAT transcript is approximately $10 \mathrm{~kb}$ in length and has five exons. No translational product is encoded in MIAT based on in vitro translation assay, which indicates that is an lncRNA. From in vitro functional analyses, MIAT transcription is increased by the minor variant of one SNP in exon 5. In contrast to the non-risk allele, the risk allele has more intense binding of nuclear protein(s). The study concluded that MIAT may play some roles in the pathogenesis of MI with altered expression by SNP [98].

Recent GWASs have identified a region on chromosome 9p that is associated with coronary artery disease (CAD) [118,119]. A long non-coding antisense RNA gene, named as Antisense non-coding RNA in the INK4 locus (ANRIL), is a prime candidate for the chromosome 9p CAD locus [64]. Several recent GWASs showed that ANRIL has increased susceptibility to intracranial aneurysm, breast cancer, glioma, and basal cell carcinomas [65-68]. ANRIL is located in the INK4b/ARF/INK4a locus, and it is coregulated with $I N K 4 a, I N K 4 b$ and $A R F$. Expression studies have confirmed that ANRIL is expressed in multiple atherosclerosis-related cell lines, including vascular endothelial cell, monocyte-derived macrophages and coronary smooth muscle cells [64,120]. Moreover, a mouse model study has demonstrated the pivotal role of ANRIL in the regulation of INK4a/b expression through a cis-acting mechanism and its implication in proliferation and senescence [121,122]. Interestingly, several studies discovered that Polycomb complexes are able to bind the INK4/ARF locus and alter expression of INK4a and $I N K 4 b[123,124]$. Similar to lncRNA XIST, the ANRIL gene presents unusual masses of repetitive elements, as well as many binding sites for repressive transcription factors [120]. All these observations suggest that ANRIL, much like XIST, may regulate the expression of the INK4a/b transcript by recruiting Polycomb complex to the INK4/ARF locus and imposing a repressive chromatin state. 


\subsection{LncRNAs in Autoimmune Diseases}

Long non-coding RNAs may also function in the regulation of downstream protein-coding genes, thus forming a complicated mutual regulation network with both coding and non-coding genes [125,126]. Recent studies have shown that autoimmune diseases, which result from an inappropriate immune response of the body against substances and tissues normally present in the body, have a complex genetic context that involves multiple protein-coding and non-coding genes. For example, in association study of 515 affected individuals and 526 controls, Shirasawa et al. discovered that the T allele of SNP Ex9b-SNP10 is correlated to increased risk for autoimmune thyroid disease (AITD) [106]. The Ex9b-SNP10 resides in intron 9 of the protein-coding gene ZFAT and the promoter region of an IncRNA, SAS-ZFAT, which is an antisense transcript of the ZFAT gene. With the existence of SNP Ex9b-SNP10, SAS-ZFAT expression is evidently upregulated, which, in turn, downregulates the expression level of its sense counterpart - truncated ZFAT. Since SAS-ZFAT is exclusively expressed in CD19+ B cells in peripheral blood lymphocytes, these results implicated that SAS-ZFAT might play a critical role in B cell function and determine susceptibility to AITD.

Another example is lncRNA PRINS, a Psoriasis Susceptibility-related non-coding RNA gene that harbors two Alu elements [103]. PRINS is transcribed by RNA polymerase II and is expressed at different levels in various human tissues. Real-time RT-PCR analysis showed that PRINS has higher expression in the uninvolved epidermis of psoriatic patients than in both psoriatic lesional and healthy epidermis, suggesting that PRINS plays a role in psoriasis susceptibility. In silico structural and homology studies have suggested that PRINS acts as a non-coding RNA. The RNA expression level of PRINS is decreased in the uninvolved psoriatic, but not healthy, epidermis with treatment of T-lymphokines that are known to precipitate psoriatic symptoms. Moreover, downregulating the RNA level of PRINS by RNAi can impair cell viability after serum starvation, but not under normal serum conditions. It was also discovered that PRINS could function as a "riboregulator" to regulate the expression of other genes involved in the proliferation and survival of cells.

\subsection{LncRNAs in Neurological Disorders}

Neurological disorders are diseases of the body's nervous systems, which include the central nervous system, the peripheral nervous system, and the autonomic nervous system. Previous transcriptome studies have shown a number of lncRNAs in the mammalian brain, and most of them exhibit particular expression profiles within specific neuroanatomical regions, cell types, or subcellular compartments, implicating that lncRNAs probably have a significant impact on neurological regulation [127].

Long non-coding RNAs may participate in the pathogenesis of fragile X syndrome (FXS) and fragile $\mathrm{X}$ tremor ataxia syndrome (FXTAS), both of which are caused by the aberrant expansion of CGG trinucleotide, repeat in the 5' UTR of protein-coding fragile-X mental retardation 1 gene $(F M R 1)[128,129]$. Studies have shown that two lncRNAs, FMR4 and ASFMR1, are expressed from the FMR1 locus. FMR4 is a primate-specific lncRNA that likely shares a bidirectional promoter with FMR1 [79], while ASFMR1 is a spliced and poly-adenylated antisense transcript that overlaps the 5' UTR CGG repeat region of FMR1 [69]. In vitro studies of FMR4 have shown that it may function to prevent neurons or their progenitors from apoptosis during the progress of development in human. FMR4 and ASFMR1, 
as well as FMR 1, may participate synergistically in neurological regulation in a RNA-protein interacting manner, since they are all silenced in FXS or upregulated in FXTAS patients. Dysregulation of these delicate interactions may result in various neurological disorders $[69,79]$.

Long non-coding RNAs have also been reported to be dysregulated in different types of neurodegenerative diseases, such as spinocerebellar ataxia type 8 (SCA8) and Alzheimer's disease (AD). SCA8 is an autosomal dominant disorder caused by repeat expansion [130]. Two bidirectionally transcribed genes are located within the SCA8 expansion region: the protein-coding gene ataxin 8 $(A T X N 8)$, with a CAG expansion that encodes a polyglutamine expansion tract protein, and ataxin 8 opposite strand (ATXN8OS) which is an lncRNA with a CUG repeat. In studies of transgenic mice expressing SCA8 expansion, it was found that the ATXN8OS mutant is overexpressed and co-localized with Muscleblind-like splicing regulator 1 (MBNL1) in neurons, which can lead to dysregulation of MBNL1-mediated alternative splicing, loss of GABAergic inhibition within the granular cell layer, and set the stage for the occurrence of disease [70]. AD is a form of dementia, which is believed to be caused by the formation of amyloid plaques in neurons [131]. Studies have shown that BACE1-AS, an antisense lncRNA counterpart of protein-coding gene $B A C E 1$, is highly expressed in tissues from $\mathrm{AD}$ patients [71]. $B A C E 1$ is an enzyme that is responsible for amyloid precursor protein (APP) cleavage into amyloid $\beta$ peptides, which form amyloid plaques in the neurons of $\mathrm{AD}$ patients [132]. Upregulation of BACE1-AS promotes the stabilization of BACE1 mRNA and boosts the expression of $B A C E 1$ protein, which leads to the production of pathogenic amyloid $\beta$ peptides and thus may speed up the pathogenesis of AD [71]. Another lncRNA involved in AD is BC200, which is expressed almost exclusively in neuronal cells. In AD patients, the level of $\mathrm{BC} 200$ becomes upregulated. The increased expression of $\mathrm{BC} 200$ was found to be correlated with the severity of AD [74]. In addition, studies of BC1, the mouse functional homolog of BC200, have shown that BC1 knockout mice exhibit behavioral changes, thus demonstrating an important role for $\mathrm{BC} 1$ in brain function [133]. All these results suggest that dysregulation of $\mathrm{BC} 200$ may contribute to AD susceptibility.

\subsection{LncRNAs in Cancers}

Cancer is a broad group of various diseases in which abnormal cells divide uncontrollably and tend to invade other tissues. Up to now, although hundreds of oncogenes and tumor suppressor genes have been identified, the exact cause of most cancers remains unknown or poorly understood. In recent years, researchers have increasingly come to recognize lncRNAs as major mediators in cancer pathogenesis [134]. Thus far, no concrete evidence has surfaced to indicate any lncRNAs as causal factors in cancer. However, many lncRNAs have been found to be differentially expressed in a variety of cancers and may act as either oncogenes, such as MALAT-1, HOTAIR, and ANRIL, or tumor suppressor genes, such as MEG3, lincRNA-p21, and PTENP1, in cancer development. Here, we discuss some examples of such lncRNAs.

Like protein-coding oncogenes, some lncRNAs can promote cell proliferation and induce tumorigenesis. Metastasis-associated lung adenocarcinoma transcript 1 (MALAT-1), which correlates with high metastasis and poor prognosis in non-small-cell lung cancer, is an abundant 8.7-kb lncRNA encoded in the human chromosome 11q13 [93]. MALAT-1 is broadly expressed in normal human tissues and is found to be upregulated in many solid tumors, such as lung, breast, prostate, liver, and 
colon tumors $[91,92,135]$. MALAT-1 is believed to play a vital role in cell proliferation, migration, and invasion. By interacting with serine-arginine-rich splicing factor $(S R)$, which is responsible for alternative splicing (AS) in a concentration- and phosphorylation-dependent manner, studies have shown that MALAT-1 can modulate the phosphorylation of $S R$ proteins and thus regulate AS of selective pre-mRNAs [136]. MALAT1 is also involved in the regulation of cell mobility. RNAi-mediated silencing of MALAT1 impaired the in vitro migration of lung adenocarcinoma cells and reduced cell proliferation and invasive potential in a cervical cancer cell line [92]. Another onco-lncRNA example is HOX Antisense Intergenic RNA (HOTAIR). HOTAIR, a 2.2-kb spliced and poly-adenylated lncRNA, is transcribed from the antisense strand of the Homeobox $\mathrm{C}$ (HOXC) gene cluster on chromosome 12 [16]. Studies have shown that HOTAIR is overexpressed in breast tumors, hepatocellular carcinoma, and colorectal cancer [137-139]. A high level of HOTAIR expression is directly correlated with poor patient prognosis and metastasis. Recent studies revealed that HOTAIR is likely to work as a molecular scaffold to bind two distinct histone modification complexes, the Polycomb repressor complex 2 (PRC2) and the histone demethylase LSD1, facilitating their genome-wide retargeting to specific regions for coupled histone H3K27 methylation and H3K4 demethylation [140]. In vitro studies have shown that overexpression of HOTAIR in cell lines leads to the recruitment of PRC2 and LSD1 to over 800 additional loci, including those of tumor suppressor genes [16]. These observations indicate that dysregulation of HOTAIR may reprogram the epigenetic information to promote tumor cell invasion and subsequent metastasis.

Long non-coding RNAs can also act as tumor suppressor genes. One example is maternally expressed gene 3 (MEG3), a maternally imprinted RNA gene of approximately 1700 nucleotides [94]. Studies have revealed that $M E G 3$ is expressed in many normal tissues, but not in the majority of human meningiomas or human meningioma cell lines [141]. Moreover, ectopic expression of MEG3 was found to suppress the growth of several human cancer cell lines, further supporting the effect of $M E G 3$ on tumor suppression [95]. MEG3 was found to be a positive regulator of $p 53$, a tumor suppressor protein [142]. In cells that are transfected with MEG3, p53 protein level increases significantly, which results in dramatically stimulating the transcription of p53-dependent genes from a p53-responsive promoter. Studies have shown that MEG3 is also capable of inhibiting cell proliferation in the absence of p53 [143]. These data suggest that MEG3 can function as a tumor suppressor through both p53-dependent and p53-independent pathways. MEG3 has a total of twelve isoforms from alternative splicing, all of which contain three distinct secondary folding motifs (M1, M2, and M3). Deletion analysis indicates that motifs M2 and M3 are important for $p 53$ activation. Furthermore, a hybrid MEG3 RNA, which contains a piece of unrelated sequence, but preserves the original secondary structure, retained the functions of both $p 53$ activation and growth suppression [144]. As a regulatory lncRNA, all of these experiments demonstrated that the proper conformation of MEG3 is critical to its biological functions.

\section{Conclusions}

Long non-coding RNAs are rapidly becoming a focal point for intensified research in the biological and medical sciences. Increasing evidence has indicated that lncRNAs play important roles in various critical biological processes and that they add a new layer of complexity to already complex human 
diseases. We believe that the further functional and mechanistic studies of these versatile macromolecules will expand our understanding of general principles in biological systems and provide new approaches to the diagnosis and treatment of complex human diseases.

\section{Acknowledgments}

This work was supported by National Natural Science Foundation of China (Grant No. 31000586) and The University of Texas at Dallas Startup Grant.

\section{Conflicts of Interest}

The authors declare no conflict of interest.

\section{References}

1. Consortium, E.P.; Dunham, I.; Kundaje, A.; Aldred, S.F.; Collins, P.J.; Davis, C.A.; Doyle, F.; Epstein, C.B.; Frietze, S.; Harrow, J.; et al. An integrated encyclopedia of DNA elements in the human genome. Nature 2012, 489, 57-74.

2. Lander, E.S.; Linton, L.M.; Birren, B.; Nusbaum, C.; Zody, M.C.; Baldwin, J.; Devon, K.; Dewar, K.; Doyle, M.; FitzHugh, W.; et al. Initial sequencing and analysis of the human genome. Nature 2001, 409, 860-921.

3. Liu, C.; Bai, B.; Skogerbo, G.; Cai, L.; Deng, W.; Zhang, Y.; Bu, D.; Zhao, Y.; Chen, R. Noncode: An integrated knowledge database of non-coding RNAs. Nucleic Acids Res. 2005, 33, D112-D115.

4. Carninci, P.; Kasukawa, T.; Katayama, S.; Gough, J.; Frith, M.C.; Maeda, N.; Oyama, R.; Ravasi, T.; Lenhard, B.; Wells, C.; et al. The transcriptional landscape of the mammalian genome. Science 2005, 309, 1559-1563.

5. Lau, N.C.; Seto, A.G.; Kim, J.; Kuramochi-Miyagawa, S.; Nakano, T.; Bartel, D.P.; Kingston, R.E. Characterization of the pirna complex from rat testes. Science 2006, 313, 363-367.

6. David, R. Small RNAs: MiRNA machinery disposal. Nat. Rev. 2013, 14, 4-5.

7. Wilusz, J.E.; Sunwoo, H.; Spector, D.L. Long noncoding RNAs: Functional surprises from the RNA world. Genes Dev. 2009, 23, 1494-1504.

8. Liao, Q.; Liu, C.; Yuan, X.; Kang, S.; Miao, R.; Xiao, H.; Zhao, G.; Luo, H.; Bu, D.; Zhao, H.; et al. Large-scale prediction of long non-coding RNA functions in a coding-non-coding gene co-expression network. Nucleic Acids Res. 2011, 39, 3864-3878.

9. Bu, D.; Yu, K.; Sun, S.; Xie, C.; Skogerbo, G.; Miao, R.; Xiao, H.; Liao, Q.; Luo, H.; Zhao, G.; et al. Noncode v3.0: Integrative annotation of long noncoding RNAs. Nucleic Acids Res. 2012, 40, D210-D215.

10. Khalil, A.M.; Guttman, M.; Huarte, M.; Garber, M.; Raj, A.; Rivea Morales, D.; Thomas, K.; Presser, A.; Bernstein, B.E.; van Oudenaarden, A.; et al. Many human large intergenic noncoding RNAs associate with chromatin-modifying complexes and affect gene expression. Proc. Natl. Acad. Sci. USA 2009, 106, 11667-11672. 
11. Mercer, T.R.; Mattick, J.S. Structure and function of long noncoding RNAs in epigenetic regulation. Nat. Struct. Mol. Biol. 2013, 20, 300-307.

12. Wang, K.C.; Chang, H.Y. Molecular mechanisms of long noncoding RNAs. Mol. Cell 2011, 43, 904-914.

13. Tufarelli, C.; Stanley, J.A.; Garrick, D.; Sharpe, J.A.; Ayyub, H.; Wood, W.G.; Higgs, D.R. Transcription of antisense RNA leading to gene silencing and methylation as a novel cause of human genetic disease. Nat. Genet. 2003, 34, 157-165.

14. Tahira, A.C.; Kubrusly, M.S.; Faria, M.F.; Dazzani, B.; Fonseca, R.S.; Maracaja-Coutinho, V.; Verjovski-Almeida, S.; Machado, M.C.; Reis, E.M. Long noncoding intronic RNAs are differentially expressed in primary and metastatic pancreatic cancer. Mol. Cancer 2011, 10, 141.

15. Chow, J.; Heard, E. X inactivation and the complexities of silencing a sex chromosome. Curr. Opin. Cell Biol. 2009, 21, 359-366.

16. Gupta, R.A.; Shah, N.; Wang, K.C.; Kim, J.; Horlings, H.M.; Wong, D.J.; Tsai, M.C.; Hung, T.; Argani, P.; Rinn, J.L.; et al. Long non-coding RNA hotair reprograms chromatin state to promote cancer metastasis. Nature 2010, 464, 1071-1076.

17. Kung, J.T.; Colognori, D.; Lee, J.T. Long noncoding RNAs: Past, present, and future. Genetics 2013, 193, 651-669.

18. Ponting, C.P.; Oliver, P.L.; Reik, W. Evolution and functions of long noncoding RNAs. Cell 2009, 136, 629-641.

19. Guttman, M.; Amit, I.; Garber, M.; French, C.; Lin, M.F.; Feldser, D.; Huarte, M.; Zuk, O.; Carey, B.W.; Cassady, J.P.; et al. Chromatin signature reveals over a thousand highly conserved large non-coding RNAs in mammals. Nature 2009, 458, 223-227.

20. Guttman, M.; Donaghey, J.; Carey, B.W.; Garber, M.; Grenier, J.K.; Munson, G.; Young, G.; Lucas, A.B.; Ach, R.; Bruhn, L.; et al. LincRNAs act in the circuitry controlling pluripotency and differentiation. Nature 2011, 477, 295-300.

21. Louro, R.; Smirnova, A.S.; Verjovski-Almeida, S. Long intronic noncoding RNA transcription: Expression noise or expression choice? Genomics 2009, 93, 291-298.

22. Yin, Y.; Zhao, Y.; Wang, J.; Liu, C.; Chen, S.; Chen, R.; Zhao, H. Anticode: A natural sense-antisense transcripts database. BMC Bioinf. 2007, 8, 319.

23. Katayama, S.; Tomaru, Y.; Kasukawa, T.; Waki, K.; Nakanishi, M.; Nakamura, M.; Nishida, H.; Yap, C.C.; Suzuki, M.; Kawai, J.; et al. Antisense transcription in the mammalian transcriptome. Science 2005, 309, 1564-1566.

24. Lehner, B.; Williams, G.; Campbell, R.D.; Sanderson, C.M. Antisense transcripts in the human genome. Trends Genet. 2002, 18, 63-65.

25. Kapranov, P.; Cheng, J.; Dike, S.; Nix, D.A.; Duttagupta, R.; Willingham, A.T.; Stadler, P.F.; Hertel, J.; Hackermuller, J.; Hofacker, I.L.; et al. RNA maps reveal new RNA classes and a possible function for pervasive transcription. Science 2007, 316, 1484-1488.

26. Preker, P.; Nielsen, J.; Kammler, S.; Lykke-Andersen, S.; Christensen, M.S.; Mapendano, C.K.; Schierup, M.H.; Jensen, T.H. RNA exosome depletion reveals transcription upstream of active human promoters. Science 2008, 322, 1851-1854. 
27. Liu, W.M.; Chu, W.M.; Choudary, P.V.; Schmid, C.W. Cell stress and translational inhibitors transiently increase the abundance of mammalian sine transcripts. Nucleic Acids Res. 1995, 23, 1758-1765.

28. Espinoza, C.A.; Goodrich, J.A.; Kugel, J.F. Characterization of the structure, function, and mechanism of b2 RNA, an ncRNA repressor of RNA polymerase II transcription. RNA 2007, 13, 583-596.

29. Mariner, P.D.; Walters, R.D.; Espinoza, C.A.; Drullinger, L.F.; Wagner, S.D.; Kugel, J.F.; Goodrich, J.A. Human Alu RNA is a modular transacting repressor of mRNA transcription during heat shock. Mol. Cell 2008, 29, 499-509.

30. Poliseno, L.; Salmena, L.; Zhang, J.; Carver, B.; Haveman, W.J.; Pandolfi, P.P. A coding-independent function of gene and pseudogene mRNAs regulates tumour biology. Nature 2010, 465, 1033-1038.

31. Salmena, L.; Poliseno, L.; Tay, Y.; Kats, L.; Pandolfi, P.P. A ceRNA hypothesis: The rosetta stone of a hidden RNA language? Cell 2011, 146, 353-358.

32. Calin, G.A.; Liu, C.G.; Ferracin, M.; Hyslop, T.; Spizzo, R.; Sevignani, C.; Fabbri, M.; Cimmino, A.; Lee, E.J.; Wojcik, S.E.; et al. Ultraconserved regions encoding ncRNAs are altered in human leukemias and carcinomas. Cancer Cell 2007, 12, 215-229.

33. Kim, T.K.; Hemberg, M.; Gray, J.M.; Costa, A.M.; Bear, D.M.; Wu, J.; Harmin, D.A.; Laptewicz, M.; Barbara-Haley, K.; Kuersten, S.; et al. Widespread transcription at neuronal activity-regulated enhancers. Nature 2010, 465, 182-187.

34. Yang, J.H.; Li, J.H.; Jiang, S.; Zhou, H.; Qu, L.H. Chipbase: A database for decoding the transcriptional regulation of long non-coding RNA and microRNA genes from chip-seq data. Nucleic Acids Res. 2013, 41, D177-D187.

35. Mituyama, T.; Yamada, K.; Hattori, E.; Okida, H.; Ono, Y.; Terai, G.; Yoshizawa, A.; Komori, T.; Asai, K. The functional RNA database 3.0: Databases to support mining and annotation of functional RNAs. Nucleic Acids Res. 2009, 37, D89-D92.

36. Volders, P.J.; Helsens, K.; Wang, X.; Menten, B.; Martens, L.; Gevaert, K.; Vandesompele, J.; Mestdagh, P. Lncipedia: A database for annotated human lncRNA transcript sequences and structures. Nucleic Acids Res. 2013, 41, D246-D251.

37. Amaral, P.P.; Clark, M.B.; Gascoigne, D.K.; Dinger, M.E.; Mattick, J.S. LncRNAdb: A reference database for long noncoding RNAs. Nucleic Acids Res. 2011, 39, D146-D151.

38. Dinger, M.E.; Pang, K.C.; Mercer, T.R.; Crowe, M.L.; Grimmond, S.M.; Mattick, J.S. Nred: A database of long noncoding RNA expression. Nucleic Acids Res. 2009, 37, D122-D126.

39. Okazaki, Y.; Furuno, M.; Kasukawa, T.; Adachi, J.; Bono, H.; Kondo, S.; Nikaido, I.; Osato, N.; Saito, R.; Suzuki, H.; et al. Analysis of the mouse transcriptome based on functional annotation of 60,770 full-length cDNAs. Nature 2002, 420, 563-573.

40. Bertone, P.; Stolc, V.; Royce, T.E.; Rozowsky, J.S.; Urban, A.E.; Zhu, X.; Rinn, J.L.; Tongprasit, W.; Samanta, M.; Weissman, S.; et al. Global identification of human transcribed sequences with genome tiling arrays. Science 2004, 306, 2242-2246.

41. Knee, R.; Murphy, P.R. Regulation of gene expression by natural antisense RNA transcripts. Neurochem. Inter. 1997, 31, 379-392. 
42. Cabili, M.N.; Trapnell, C.; Goff, L.; Koziol, M.; Tazon-Vega, B.; Regev, A.; Rinn, J.L. Integrative annotation of human large intergenic noncoding RNAs reveals global properties and specific subclasses. Genes Dev. 2011, 25, 1915-1927.

43. Huarte, M.; Guttman, M.; Feldser, D.; Garber, M.; Koziol, M.J.; Kenzelmann-Broz, D.; Khalil, A.M.; Zuk, O.; Amit, I.; Rabani, M., et al. A large intergenic noncoding RNA induced by p53 mediates global gene repression in the p53 response. Cell 2010, 142, 409-419.

44. Wang, J.; Zhang, J.; Zheng, H.; Li, J.; Liu, D.; Li, H.; Samudrala, R.; Yu, J.; Wong, G.K. Mouse transcriptome: Neutral evolution of "non-coding" complementary DNAs. Nature 2004, 431, doi:10.1038/nature03016.

45. Kutter, C.; Watt, S.; Stefflova, K.; Wilson, M.D.; Goncalves, A.; Ponting, C.P.; Odom, D.T.; Marques, A.C. Rapid turnover of long noncoding RNAs and the evolution of gene expression. PLoS Genet. 2012, 8, e1002841.

46. Pang, K.C.; Frith, M.C.; Mattick, J.S. Rapid evolution of noncoding RNAs: Lack of conservation does not mean lack of function. Trends Genet. 2006, 22, 1-5.

47. Nagano, T.; Mitchell, J.A.; Sanz, L.A.; Pauler, F.M.; Ferguson-Smith, A.C.; Feil, R.; Fraser, P. The air noncoding RNA epigenetically silences transcription by targeting g9a to chromatin. Science 2008, 322, 1717-1720.

48. Leeb, M.; Steffen, P.A.; Wutz, A. X chromosome inactivation sparked by non-coding RNAs. RNA Biol. 2009, 6, 94-99.

49. Pollard, K.S.; Salama, S.R.; Lambert, N.; Lambot, M.A.; Coppens, S.; Pedersen, J.S.; Katzman, S.; King, B.; Onodera, C.; Siepel, A.; et al. An RNA gene expressed during cortical development evolved rapidly in humans. Nature 2006, 443, 167-172.

50. Leontis, N.B.; Westhof, E. Analysis of RNA motifs. Curr. Opin. Struct. Biol. 2003, 13, 300-308.

51. Bejerano, G.; Pheasant, M.; Makunin, I.; Stephen, S.; Kent, W.J.; Mattick, J.S.; Haussler, D. Ultraconserved elements in the human genome. Science 2004, 304, 1321-1325.

52. Chen, C.T.; Wang, J.C.; Cohen, B.A. The strength of selection on ultraconserved elements in the human genome. Am. J. Hum. Genet. 2007, 80, 692-704.

53. Katzman, S.; Kern, A.D.; Bejerano, G.; Fewell, G.; Fulton, L.; Wilson, R.K.; Salama, S.R.; Haussler, D. Human genome ultraconserved elements are ultraselected. Science 2007, 317, 915.

54. Catucci, I.; Verderio, P.; Pizzamiglio, S.; Manoukian, S.; Peissel, B.; Barile, M.; Tizzoni, L.; Bernard, L.; Ravagnani, F.; Galastri, L.; et al. Snps in ultraconserved elements and familial breast cancer risk. Carcinogenesis 2009, 30, 544-545.

55. Scaruffi, P.; Stigliani, S.; Moretti, S.; Coco, S.; de Vecchi, C.; Valdora, F.; Garaventa, A.; Bonassi, S.; Tonini, G.P. Transcribed-ultra conserved region expression is associated with outcome in high-risk neuroblastoma. BMC Cancer 2009, 9, 441.

56. Orom, U.A.; Derrien, T.; Beringer, M.; Gumireddy, K.; Gardini, A.; Bussotti, G.; Lai, F.; Zytnicki, M.; Notredame, C.; Huang, Q.; et al. Long noncoding RNAs with enhancer-like function in human cells. Cell 2010, 143, 46-58.

57. Willingham, A.T.; Orth, A.P.; Batalov, S.; Peters, E.C.; Wen, B.G.; Aza-Blanc, P.; Hogenesch, J.B.; Schultz, P.G. A strategy for probing the function of noncoding RNAs finds a repressor of nfat. Science 2005, 309, 1570-1573. 
58. Silva, J.M.; Perez, D.S.; Pritchett, J.R.; Halling, M.L.; Tang, H.; Smith, D.I. Identification of long stress-induced non-coding transcripts that have altered expression in cancer. Genomics 2010, 95, 355-362.

59. Hunter, D.J. Gene-environment interactions in human diseases. Nat. Rev. 2005, 6, 287-298.

60. Liu, L.; Li, Y.; Tollefsbol, T.O. Gene-environment interactions and epigenetic basis of human diseases. Curr. Issues Mol. Biol. 2008, 10, 25-36.

61. Thrash-Bingham, C.A.; Tartof, K.D. Ahif: A natural antisense transcript overexpressed in human renal cancer and during hypoxia. J. Natl. Cancer Inst. 1999, 91, 143-151.

62. Cayre, A.; Rossignol, F.; Clottes, E.; Penault-Llorca, F. Ahif but not hif-1alpha transcript is a poor prognostic marker in human breast cancer. Breast Cancer Res. 2003, 5, R223-R230.

63. He, H.; Nagy, R.; Liyanarachchi, S.; Jiao, H.; Li, W.; Suster, S.; Kere, J.; de la Chapelle, A. A susceptibility locus for papillary thyroid carcinoma on chromosome 8q24. Cancer Res. 2009, 69, 625-631.

64. Broadbent, H.M.; Peden, J.F.; Lorkowski, S.; Goel, A.; Ongen, H.; Green, F.; Clarke, R.; Collins, R.; Franzosi, M.G.; Tognoni, G.; et al. Susceptibility to coronary artery disease and diabetes is encoded by distinct, tightly linked snps in the anril locus on chromosome 9p. Hum. Mol. Genet. 2008, 17, 806-814.

65. Yasuno, K.; Bilguvar, K.; Bijlenga, P.; Low, S.K.; Krischek, B.; Auburger, G.; Simon, M.; Krex, D.; Arlier, Z.; Nayak, N.; et al. Genome-wide association study of intracranial aneurysm identifies three new risk loci. Nat. Genet. 2010, 42, 420-425.

66. Shete, S.; Hosking, F.J.; Robertson, L.B.; Dobbins, S.E.; Sanson, M.; Malmer, B.; Simon, M.; Marie, Y.; Boisselier, B.; Delattre, J.Y.; et al. Genome-wide association study identifies five susceptibility loci for glioma. Nat. Genet. 2009, 41, 899-904.

67. Stacey, S.N.; Sulem, P.; Masson, G.; Gudjonsson, S.A.; Thorleifsson, G.; Jakobsdottir, M.; Sigurdsson, A.; Gudbjartsson, D.F.; Sigurgeirsson, B.; Benediktsdottir, K.R.; et al. New common variants affecting susceptibility to basal cell carcinoma. Nat. Genet. 2009, 41, 909-914.

68. Turnbull, C.; Ahmed, S.; Morrison, J.; Pernet, D.; Renwick, A.; Maranian, M.; Seal, S.; Ghoussaini, M.; Hines, S.; Healey, C.S.; et al. Genome-wide association study identifies five new breast cancer susceptibility loci. Nat. Genet. 2010, 42, 504-507.

69. Ladd, P.D.; Smith, L.E.; Rabaia, N.A.; Moore, J.M.; Georges, S.A.; Hansen, R.S.; Hagerman, R.J.; Tassone, F.; Tapscott, S.J.; Filippova, G.N. An antisense transcript spanning the cgg repeat region of fmr1 is upregulated in premutation carriers but silenced in full mutation individuals. Hum. Mol. Genet. 2007, 16, 3174-3187.

70. Moseley, M.L.; Zu, T.; Ikeda, Y.; Gao, W.; Mosemiller, A.K.; Daughters, R.S.; Chen, G.; Weatherspoon, M.R.; Clark, H.B.; Ebner, T.J.; et al. Bidirectional expression of cug and cag expansion transcripts and intranuclear polyglutamine inclusions in spinocerebellar ataxia type 8 . Nat. Genet. 2006, 38, 758-769.

71. Faghihi, M.A.; Modarresi, F.; Khalil, A.M.; Wood, D.E.; Sahagan, B.G.; Morgan, T.E.; Finch, C.E.; St Laurent, G., III; Kenny, P.J.; Wahlestedt, C. Expression of a noncoding RNA is elevated in Alzheimer's disease and drives rapid feed-forward regulation of beta-secretase. Nat. Med. 2008, 14, 723-730. 
72. Chen, W.; Bocker, W.; Brosius, J.; Tiedge, H. Expression of neural bc200 RNA in human tumours. J. Pathol. 1997, 183, 345-351.

73. Iacoangeli, A.; Lin, Y.; Morley, E.J.; Muslimov, I.A.; Bianchi, R.; Reilly, J.; Weedon, J.; Diallo, R.; Bocker, W.; Tiedge, H. Bc200 RNA in invasive and preinvasive breast cancer. Carcinogenesis 2004, 25, 2125-2133.

74. Mus, E.; Hof, P.R.; Tiedge, H. Dendritic bc200 RNA in aging and in Alzheimer's disease. Proc. Natl. Acad. Sci. USA 2007, 104, 10679-10684.

75. Eis, P.S.; Tam, W.; Sun, L.; Chadburn, A.; Li, Z.; Gomez, M.F.; Lund, E.; Dahlberg, J.E. Accumulation of mir-155 and bic RNA in human b cell lymphomas. Proc. Natl. Acad. Sci. USA 2005, 102, 3627-3632.

76. Tsang, W.P.; Wong, T.W.; Cheung, A.H.; Co, C.N.; Kwok, T.T. Induction of drug resistance and transformation in human cancer cells by the noncoding RNA cudr. RNA 2007, 13, 890-898.

77. Bussemakers, M.J.; van Bokhoven, A.; Verhaegh, G.W.; Smit, F.P.; Karthaus, H.F.; Schalken, J.A.; Debruyne, F.M.; Ru, N.; Isaacs, W.B. Dd3: A new prostate-specific gene, highly overexpressed in prostate cancer. Cancer Res. 1999, 59, 5975-5979.

78. De Kok, J.B.; Verhaegh, G.W.; Roelofs, R.W.; Hessels, D.; Kiemeney, L.A.; Aalders, T.W.; Swinkels, D.W.; Schalken, J.A. Dd3(pca3), a very sensitive and specific marker to detect prostate tumors. Cancer Res. 2002, 62, 2695-2698.

79. Khalil, A.M.; Faghihi, M.A.; Modarresi, F.; Brothers, S.P.; Wahlestedt, C. A novel RNA transcript with antiapoptotic function is silenced in fragile x syndrome. PLoS One 2008, 3, e1486.

80. Mourtada-Maarabouni, M.; Pickard, M.R.; Hedge, V.L.; Farzaneh, F.; Williams, G.T. Gas5, a non-protein-coding RNA, controls apoptosis and is downregulated in breast cancer. Oncogene 2009, 28, 195-208.

81. Brannan, C.I.; Dees, E.C.; Ingram, R.S.; Tilghman, S.M. The product of the h19 gene may function as an RNA. Mol. Cell. Biol. 1990, 10, 28-36.

82. Gabory, A.; Jammes, H.; Dandolo, L. The h19 locus: Role of an imprinted non-coding RNA in growth and development. BioEssays 2010, 32, 473-480.

83. Matouk, I.J.; DeGroot, N.; Mezan, S.; Ayesh, S.; Abu-lail, R.; Hochberg, A.; Galun, E. The h19 non-coding RNA is essential for human tumor growth. PLoS One 2007, 2, e845.

84. Yang, F.; Bi, J.; Xue, X.; Zheng, L.; Zhi, K.; Hua, J.; Fang, G. Up-regulated long non-coding RNA h19 contributes to proliferation of gastric cancer cells. FEBS J. 2012, 279, 3159-3165.

85. Luo, M.; Li, Z.; Wang, W.; Zeng, Y.; Liu, Z.; Qiu, J. Long non-coding RNA h19 increases bladder cancer metastasis by associating with ezh2 and inhibiting e-cadherin expression. Cancer Lett. 2013, 333, 213-221.

86. Rinn, J.L.; Kertesz, M.; Wang, J.K.; Squazzo, S.L.; Xu, X.; Brugmann, S.A.; Goodnough, L.H.; Helms, J.A.; Farnham, P.J.; Segal, E.; et al. Functional demarcation of active and silent chromatin domains in human hox loci by noncoding RNAs. Cell 2007, 129, 1311-1323.

87. Panzitt, K.; Tschernatsch, M.M.; Guelly, C.; Moustafa, T.; Stradner, M.; Strohmaier, H.M.; Buck, C.R.; Denk, H.; Schroeder, R.; Trauner, M.; et al. Characterization of hulc, a novel gene with striking up-regulation in hepatocellular carcinoma, as noncoding RNA. Gastroenterology 2007, 132, 330-342. 
88. Matouk, I.J.; Abbasi, I.; Hochberg, A.; Galun, E.; Dweik, H.; Akkawi, M. Highly upregulated in liver cancer noncoding RNA is overexpressed in hepatic colorectal metastasis. Eur. J. Gastroenterol. Hepatol. 2009, 21, 688-692.

89. Tanaka, K.; Shiota, G.; Meguro, M.; Mitsuya, K.; Oshimura, M.; Kawasaki, H. Loss of imprinting of long qt intronic transcript 1 in colorectal cancer. Oncology 2001, 60, 268-273.

90. Pasic, I.; Shlien, A.; Durbin, A.D.; Stavropoulos, D.J.; Baskin, B.; Ray, P.N.; Novokmet, A.; Malkin, D. Recurrent focal copy-number changes and loss of heterozygosity implicate two noncoding RNAs and one tumor suppressor gene at chromosome 3q13.31 in osteosarcoma. Cancer Res. 2010, 70, 160-171.

91. Ying, L.; Chen, Q.; Wang, Y.; Zhou, Z.; Huang, Y.; Qiu, F. Upregulated malat-1 contributes to bladder cancer cell migration by inducing epithelial-to-mesenchymal transition. Mol. Biosyst. 2012, 8, 2289-2294.

92. Tano, K.; Mizuno, R.; Okada, T.; Rakwal, R.; Shibato, J.; Masuo, Y.; Ijiri, K.; Akimitsu, N. Malat-1 enhances cell motility of lung adenocarcinoma cells by influencing the expression of motility-related genes. FEBS Lett. 2010, 584, 4575-4580.

93. Ji, P.; Diederichs, S.; Wang, W.; Boing, S.; Metzger, R.; Schneider, P.M.; Tidow, N.; Brandt, B.; Buerger, H.; Bulk, E.; et al. Malat-1, a novel noncoding RNA, and thymosin beta4 predict metastasis and survival in early-stage non-small cell lung cancer. Oncogene 2003, 22, 8031-8041.

94. Miyoshi, N.; Wagatsuma, H.; Wakana, S.; Shiroishi, T.; Nomura, M.; Aisaka, K.; Kohda, T.; Surani, M.A.; Kaneko-Ishino, T.; Ishino, F. Identification of an imprinted gene, meg3/gtl2 and its human homologue meg3, first mapped on mouse distal chromosome 12 and human chromosome 14q. Genes Cells 2000, 5, 211-220.

95. Zhang, X.; Zhou, Y.; Mehta, K.R.; Danila, D.C.; Scolavino, S.; Johnson, S.R.; Klibanski, A. A pituitary-derived meg3 isoform functions as a growth suppressor in tumor cells. J. Clin. Endocrinol. Metab. 2003, 88, 5119-5126.

96. Braconi, C.; Kogure, T.; Valeri, N.; Huang, N.; Nuovo, G.; Costinean, S.; Negrini, M.; Miotto, E.; Croce, C.M.; Patel, T. MicroRNA-29 can regulate expression of the long non-coding RNA gene meg3 in hepatocellular cancer. Oncogene 2011, 30, 4750-4756.

97. Ying, L.; Huang, Y.; Chen, H.; Wang, Y.; Xia, L.; Chen, Y.; Liu, Y.; Qiu, F. Downregulated meg3 activates autophagy and increases cell proliferation in bladder cancer. Mol. Biosyst. 2013, 9, 407-411.

98. Ishii, N.; Ozaki, K.; Sato, H.; Mizuno, H.; Saito, S.; Takahashi, A.; Miyamoto, Y.; Ikegawa, S.; Kamatani, N.; Hori, M.; et al. Identification of a novel non-coding RNA, miat, that confers risk of myocardial infarction. J. Hum. Genet. 2006, 51, 1087-1099.

99. Yu, M.; Ohira, M.; Li, Y.; Niizuma, H.; Oo, M.L.; Zhu, Y.; Ozaki, T.; Isogai, E.; Nakamura, Y.; Koda, T.; et al. High expression of ncran, a novel non-coding RNA mapped to chromosome 17q25.1, is associated with poor prognosis in neuroblastoma. Int. J. Oncol. 2009, 34, 931-938.

100. Zhu, Y.; Yu, M.; Li, Z.; Kong, C.; Bi, J.; Li, J.; Gao, Z.; Li, Z. Ncran, a newly identified long noncoding RNA, enhances human bladder tumor growth, invasion, and survival. Urology 2011, 77, e511-e515. 
101. Castelnuovo, M.; Massone, S.; Tasso, R.; Fiorino, G.; Gatti, M.; Robello, M.; Gatta, E.; Berger, A.; Strub, K.; Florio, T.; et al. An alu-like RNA promotes cell differentiation and reduces malignancy of human neuroblastoma cells. FASEB J. 2010, 24, 4033-4046.

102. Petrovics, G.; Zhang, W.; Makarem, M.; Street, J.P.; Connelly, R.; Sun, L.; Sesterhenn, I.A.; Srikantan, V.; Moul, J.W.; Srivastava, S., Elevated expression of pcgem1, a prostate-specific gene with cell growth-promoting function, is associated with high-risk prostate cancer patients. Oncogene 2004, 23, 605-611.

103. Sonkoly, E.; Bata-Csorgo, Z.; Pivarcsi, A.; Polyanka, H.; Kenderessy-Szabo, A.; Molnar, G.; Szentpali, K.; Bari, L.; Megyeri, K.; Mandi, Y.; et al. Identification and characterization of a novel, psoriasis susceptibility-related noncoding RNA gene, prins. J. Biol. Chem. 2005, 280, 24159-24167.

104. Chung, S.; Nakagawa, H.; Uemura, M.; Piao, L.; Ashikawa, K.; Hosono, N.; Takata, R.; Akamatsu, S.; Kawaguchi, T.; Morizono, T.; et al. Association of a novel long non-coding RNA in 8q24 with prostate cancer susceptibility. Cancer Sci. 2011, 102, 245-252.

105. Maida, Y.; Yasukawa, M.; Furuuchi, M.; Lassmann, T.; Possemato, R.; Okamoto, N.; Kasim, V.; Hayashizaki, Y.; Hahn, W.C.; Masutomi, K. An RNA-dependent RNA polymerase formed by tert and the rmrp RNA. Nature 2009, 461, 230-235.

106. Shirasawa, S.; Harada, H.; Furugaki, K.; Akamizu, T.; Ishikawa, N.; Ito, K.; Ito, K.; Tamai, H.; Kuma, K.; Kubota, S.; et al. Snps in the promoter of a b cell-specific antisense transcript, sas-zfat, determine susceptibility to autoimmune thyroid disease. Hum. Mol. Genet. 2004, 13, 2221-2231.

107. Khaitan, D.; Dinger, M.E.; Mazar, J.; Crawford, J.; Smith, M.A.; Mattick, J.S.; Perera, R.J. The melanoma-upregulated long noncoding RNA spry4-it1 modulates apoptosis and invasion. Cancer Res. 2011, 71, 3852-3862.

108. Leygue, E. Steroid receptor RNA activator (sra1): Unusual bifaceted gene products with suspected relevance to breast cancer. Nucl. Recept. Signaling 2007, 5, e006.

109. Chooniedass-Kothari, S.; Hamedani, M.K.; Troup, S.; Hube, F.; Leygue, E. The steroid receptor RNA activator protein is expressed in breast tumor tissues. Int. J. Cancer 2006, 118, 1054-1059.

110. Cao, Y.; Bryan, T.M.; Reddel, R.R. Increased copy number of the tert and terc telomerase subunit genes in cancer cells. Cancer Sci. 2008, 99, 1092-1099.

111. Mishra, A.; Godavarthi, S.K.; Jana, N.R. Ube3a/e6-ap regulates cell proliferation by promoting proteasomal degradation of p27. Neurobiol. Dis. 2009, 36, 26-34.

112. Numata, K.; Kohama, C.; Abe, K.; Kiyosawa, H. Highly parallel snp genotyping reveals high-resolution landscape of mono-allelic ube3a expression associated with locus-wide antisense transcription. Nucleic Acids Res. 2011, 39, 2649-2657.

113. Wang, F.; Li, X.; Xie, X.; Zhao, L.; Chen, W. Uca1, a non-protein-coding RNA up-regulated in bladder carcinoma and embryo, influencing cell growth and promoting invasion. FEBS Lett. 2008, 582, 1919-1927.

114. Wang, X.S.; Zhang, Z.; Wang, H.C.; Cai, J.L.; Xu, Q.W.; Li, M.Q.; Chen, Y.C.; Qian, X.P.; Lu, T.J.; Yu, L.Z.; et al. Rapid identification of ucal as a very sensitive and specific unique marker for human bladder carcinoma. Clin. Cancer Res. 2006, 12, 4851-4858. 
115. Yang, C.; Li, X.; Wang, Y.; Zhao, L.; Chen, W. Long non-coding RNA uca1 regulated cell cycle distribution via creb through pi3-k dependent pathway in bladder carcinoma cells. Gene 2012, 496, 8-16.

116. Askarian-Amiri, M.E.; Crawford, J.; French, J.D.; Smart, C.E.; Smith, M.A.; Clark, M.B.; $\mathrm{Ru}, \mathrm{K} . ;$ Mercer, T.R.; Thompson, E.R.; Lakhani, S.R.; et al. Snord-host RNA zfas1 is a regulator of mammary development and a potential marker for breast cancer. RNA 2011, 17, 878-891.

117. Visscher, P.M.; Brown, M.A.; McCarthy, M.I.; Yang, J. Five years of gwas discovery. Am. J. Hum. Genet. 2012, 90, 7-24.

118. McPherson, R.; Pertsemlidis, A.; Kavaslar, N.; Stewart, A.; Roberts, R.; Cox, D.R.; Hinds, D.A.; Pennacchio, L.A.; Tybjaerg-Hansen, A.; Folsom, A.R.; et al. A common allele on chromosome 9 associated with coronary heart disease. Science 2007, 316, 1488-1491.

119. Samani, N.J.; Erdmann, J.; Hall, A.S.; Hengstenberg, C.; Mangino, M.; Mayer, B.; Dixon, R.J.; Meitinger, T.; Braund, P.; Wichmann, H.E.; et al. Genomewide association analysis of coronary artery disease. N. Engl. J. Med. 2007, 357, 443-453.

120. Jarinova, O.; Stewart, A.F.; Roberts, R.; Wells, G.; Lau, P.; Naing, T.; Buerki, C.; McLean, B.W.; Cook, R.C.; Parker, J.S.; et al. Functional analysis of the chromosome 9p21.3 coronary artery disease risk locus. Arterioscler. Thromb. Vasc. Biol. 2009, 29, 1671-1677.

121. Pasmant, E.; Sabbagh, A.; Vidaud, M.; Bieche, I. Anril, a long, noncoding RNA, is an unexpected major hotspot in gwas. FASEB J. 2011, 25, 444-448.

122. Visel, A.; Zhu, Y.; May, D.; Afzal, V.; Gong, E.; Attanasio, C.; Blow, M.J.; Cohen, J.C.; Rubin, E.M.; Pennacchio, L.A. Targeted deletion of the 9p21 non-coding coronary artery disease risk interval in mice. Nature 2010, 464, 409-412.

123. Yap, K.L.; Li, S.; Munoz-Cabello, A.M.; Raguz, S.; Zeng, L.; Mujtaba, S.; Gil, J.; Walsh, M.J.; Zhou, M.M. Molecular interplay of the noncoding RNA anril and methylated histone h3 lysine 27 by polycomb cbx7 in transcriptional silencing of ink4a. Mol. Cell 2010, 38, 662-674.

124. El Messaoudi-Aubert, S.; Nicholls, J.; Maertens, G.N.; Brookes, S.; Bernstein, E.; Peters, G. Role for the mov10 RNA helicase in polycomb-mediated repression of the ink4a tumor suppressor. Nat. Struct. Mol. Biol. 2010, 17, 862-868.

125. He, S.; Su, H.; Liu, C.; Skogerbo, G.; He, H.; He, D.; Zhu, X.; Liu, T.; Zhao, Y.; Chen, R. MicroRNA-encoding long non-coding RNAs. BMC Genom. 2008, 9, 236.

126. Zhao, Y.; He, S.; Liu, C.; Ru, S.; Zhao, H.; Yang, Z.; Yang, P.; Yuan, X.; Sun, S.; Bu, D.; et al. MicroRNA regulation of messenger-like noncoding RNAs: A network of mutual microRNA control. Trends Genet. 2008, 24, 323-327.

127. Mercer, T.R.; Dinger, M.E.; Sunkin, S.M.; Mehler, M.F.; Mattick, J.S. Specific expression of long noncoding RNAs in the mouse brain. Proc. Natl. Acad. Sci. USA 2008, 105, 716-721.

128. Hagerman, P.J.; Hagerman, R.J. Fragile x-associated tremor/ataxia syndrome-An older face of the fragile x gene. Nat. Clin. Pract. Neurol. 2007, 3, 107-112.

129. Jacquemont, S.; Hagerman, R.J.; Hagerman, P.J.; Leehey, M.A. Fragile-x syndrome and fragile $\mathrm{X}$-associated tremor/ataxia syndrome: Two faces of fmr1. Lancet Neurol. 2007, 6, 45-55.

130. Nemes, J.P.; Benzow, K.A.; Moseley, M.L.; Ranum, L.P.; Koob, M.D. The sca8 transcript is an antisense RNA to a brain-specific transcript encoding a novel actin-binding protein (klhl1). Hum. Mol. Genet. 2000, 9, 1543-1551. 
131. Berchtold, N.C.; Cotman, C.W. Evolution in the conceptualization of dementia and Alzheimer's disease: Greco-roman period to the 1960s. Neurobiol. Aging 1998, 19, 173-189.

132. Fleck, D.; Garratt, A.N.; Haass, C.; Willem, M. Bace1 dependent neuregulin processing: Review. Curr. Alzheimer Res. 2012, 9, 178-183.

133. Lewejohann, L.; Skryabin, B.V.; Sachser, N.; Prehn, C.; Heiduschka, P.; Thanos, S.; Jordan, U.; Dell'Omo, G.; Vyssotski, A.L.; Pleskacheva, M.G.; et al. Role of a neuronal small non-messenger RNA: Behavioural alterations in bc1 RNA-deleted mice. Behav. Brain Res. 2004, 154, 273-289.

134. Qiu, M.T.; Hu, J.W.; Yin, R.; Xu, L. Long noncoding RNA: An emerging paradigm of cancer research. Tumour Biol. 2013, 34, 613-620.

135. Xu, C.; Yang, M.; Tian, J.; Wang, X.; Li, Z. Malat-1: A long non-coding RNA and its important 3' end functional motif in colorectal cancer metastasis. Int. J. Oncol. 2011, 39, 169-175.

136. Tripathi, V.; Ellis, J.D.; Shen, Z.; Song, D.Y.; Pan, Q.; Watt, A.T.; Freier, S.M.; Bennett, C.F.; Sharma, A.; Bubulya, P.A.; et al. The nuclear-retained noncoding RNA malat1 regulates alternative splicing by modulating sr splicing factor phosphorylation. Mol. Cell 2010, 39, 925-938.

137. Lu, L.; Zhu, G.; Zhang, C.; Deng, Q.; Katsaros, D.; Mayne, S.T.; Risch, H.A.; Mu, L.; Canuto, E.M.; Gregori, G.; et al. Association of large noncoding RNA hotair expression and its downstream intergenic cpg island methylation with survival in breast cancer. Breast Cancer Res. Treat. 2012, 136, 875-883.

138. Ishibashi, M.; Kogo, R.; Shibata, K.; Sawada, G.; Takahashi, Y.; Kurashige, J.; Akiyoshi, S.; Sasaki, S.; Iwaya, T.; Sudo, T.; et al. Clinical significance of the expression of long non-coding RNA hotair in primary hepatocellular carcinoma. Oncol. Rep. 2013, 29, 946-950.

139. Kogo, R.; Shimamura, T.; Mimori, K.; Kawahara, K.; Imoto, S.; Sudo, T.; Tanaka, F.; Shibata, K.; Suzuki, A.; Komune, S.; et al. Long noncoding RNA hotair regulates polycomb-dependent chromatin modification and is associated with poor prognosis in colorectal cancers. Cancer Res. 2011, 71, 6320-6326.

140. Tsai, M.C.; Manor, O.; Wan, Y.; Mosammaparast, N.; Wang, J.K.; Lan, F.; Shi, Y.; Segal, E.; Chang, H.Y. Long noncoding RNA as modular scaffold of histone modification complexes. Science 2010, 329, 689-693.

141. Zhang, X.; Gejman, R.; Mahta, A.; Zhong, Y.; Rice, K.A.; Zhou, Y.; Cheunsuchon, P.; Louis, D.N.; Klibanski, A. Maternally expressed gene 3, an imprinted noncoding RNA gene, is associated with meningioma pathogenesis and progression. Cancer Res. 2010, 70, 2350-2358.

142. Cho, Y.; Gorina, S.; Jeffrey, P.D.; Pavletich, N.P. Crystal structure of a p53 tumor suppressor-DNA complex: Understanding tumorigenic mutations. Science 1994, 265, 346-355.

143. Zhou, Y.; Zhong, Y.; Wang, Y.; Zhang, X.; Batista, D.L.; Gejman, R.; Ansell, P.J.; Zhao, J.; Weng, C.; Klibanski, A. Activation of p53 by meg3 non-coding RNA. J. Biol. Chem. 2007, 282, 24731-24742.

144. Zhang, X.; Rice, K.; Wang, Y.; Chen, W.; Zhong, Y.; Nakayama, Y.; Zhou, Y.; Klibanski, A. Maternally expressed gene 3 (meg3) noncoding ribonucleic acid: Isoform structure, expression, and functions. Endocrinology 2010, 151, 939-947.

(C) 2013 by the authors; licensee MDPI, Basel, Switzerland. This article is an open access article distributed under the terms and conditions of the Creative Commons Attribution license (http://creativecommons.org/licenses/by/3.0/). 